Review

\title{
Impact of Car Sharing on Urban Sustainability
}

\author{
Vasja Roblek ${ }^{1}\left(\mathbb{D}\right.$, Maja Meško ${ }^{2,3}$ a and Iztok Podbregar ${ }^{3, *}$ \\ 1 Faculty of Organisation Studies in Novo Mesto, 8000 Novo Mesto, Slovenia; vasja.roblek@gmx.com \\ 2 Faculty of Management, University of Primorska, 6000 Koper, Slovenia; maja.mesko@fm-kp.si \\ 3 Faculty of Organizational Sciences, University of Maribor, $4000 \mathrm{Kranj}$, Slovenia \\ * Correspondence: iztok.podbregar@um.si
}

\begin{abstract}
The article gives us an insight into the key issues of car sharing and its impact on urban sustainability. A selection of 314 articles published in peer-reviewed journals from the Scopus database were analysed using Leximancer 5.0 for Automated Content analysis. A total of seven themes were identified explaining the researched topic of the car sharing situation in Europe, which are sharing, economy, model, systems, electrical car sharing, policy and travel. There are two ways of sharing owned cars in Europe; access to cars from the fleet of private organisations and P2P car sharing. Sustainable environmental solutions in the context of the electrification of cars are used. Car sharing usually takes place online and can be free or for a fee as defined by The European Economic and Social Committee. The article provides an overview of understanding the concept of urban car sharing in Europe.
\end{abstract}

Keywords: sustainability; urban sustainability; car sharing; Europe

Citation: Roblek, V.; Meško, M.; Podbregar, I. Impact of Car Sharing on Urban Sustainability. Sustainability 2021, 13, 905. https://doi.org/ $10.3390 /$ su13020905

Received: 30 December 2020

Accepted: 14 January 2021

Published: 18 January 2021

Publisher's Note: MDPI stays neutral with regard to jurisdictional claims in published maps and institutional affiliations.

Copyright: (C) 2021 by the authors. Licensee MDPI, Basel, Switzerland. This article is an open access article distributed under the terms and conditions of the Creative Commons Attribution (CC BY) license (https:// creativecommons.org/licenses/by/ $4.0 /)$.

\section{Introduction}

This article aims to provide an overview of understanding the concept of urban car sharing, whose growth and development has been influenced by the recent financial crisis that caused an economic recession in both the US and Europe between 2007 and mid-2009, the emergence of the fourth industrial revolution that introduces new digital solutions for car sharing, the different social value system of the younger generations $\mathrm{Y}$ and $\mathrm{Z}$, and the breakout of COVID-19 in 2020.

In the context of the fourth industrial revolution, which accelerated the development of community-based digital platforms and the use of Big Data, there was a boom in the sharing economy as a peer-to-peer (P2P) economic model whose activities are associated with the acquisition, provision or sharing of goods and services between individuals or between businesses and individuals (B2C) and business-to-business (B2B) [1]. One of the essential characteristics of sharing is that it can be free or pays the cost of sharing. The sharing economy's first applications were observed in durable goods such as cars and houses [2].

Socio-demographic factors are also important for the growth of the car sharing model in the last decade. It is evident that younger generations have a somewhat different value system and do not consider material goods ownership as necessary. As a result, they are increasingly advocating a sharing economy, an economy that values universal access over ownership [3,4]. In this way, a good is available to multiple users, and there is no longer an intermediary between the provider and the demander. People are enthusiastic about this concept because it entails lower costs of use or rent. In addition to the financial savings, it also brings savings in storage space and, last but not least, it has an ecological touch, because fewer things usually cause less waste $[5,6]$.

The article focuses on the analysis of academic texts written by social researchers dealing not only with environmental issues in cities where car sharing plays a positive role in the social environment but also with the problems they face in cities where a ride-hailing 
type of car sharing service such as Uber (so-called social cost of Uber) [7-9] is introduced, and finally with the influence of the COVID-19 $[10,11]$ on the changes of the service to provide a safe and sustainable sharing business model. Considering the far-reaching importance of the sharing economy, the article explores the car sharing model's significance and situation in Europe. Based on the academic work, the authors developed a research question: what are the core problems of car sharing as a sustainable economic model in Europe?

In Germany, the largest market for car sharing in Europe-the number of users has increased from 0.26 million in 2012 to 1.29 million in 2020 [12] — have also been recognised the risks of this economic model. For example, experts point out that there is no planned decline in car ownership, that there are differences between urban and regional areas, that Germans have a particularly emotional attachment to car ownership and that younger users value high-performance cars from well-known brands [13]. Car sharing providers in Europe also face local legislation problems, differences in consumer behaviour and local transport competition 9. In Germany, for example, a court in Frankfurt has banned Uber from operating as a ride-hailing service in 2019 [14]. It is also worth mentioning the impact of the coronavirus pandemic and possible phenomena in the coming years that could affect the model's performance. The general criticism of the sharing economy refers to the regulatory uncertainty, the lack of government supervision, and the security of the online platform users' information. When sharing information with the online platform, it is also important to know the possibility of racial and/or sexual bias due to algorithms $[15,16]$.

This review article presents a car sharing economy based on the analysis of research articles published over a period from 2011 to 2020. Since there are many articles, it is necessary to adopt an alternative analytical approach that can effectively and successfully categorise large amounts of data. It is this analysed data that enables the researcher to explain the research phenomenon adequately and comprehensibly. For the topic discussed here, the automated content analysis (ACA) method was used to identify key themes and concepts of interest to the researcher [17].

This thesis consists of the following sections: introduction, followed by the research method, including data collection and literature selection. The following chapters contain data analysis and ACA findings. The paper concludes with a discussion of the findings and conclusions, including a comparative analysis of the results, research limitations, and future research suggestions.

\section{Data Sources and Method}

\subsection{Data Source and Data Collection}

The selection of the papers was made in the following steps. In the first step, the authors used the Scopus platform to search for and identify the scientific articles on thematic car sharing in Europe. The authors used a logical combination of keywords to find the relevant article: TITLE-ABS-KEY $\left({ }^{*}\right.$ Carsharing) AND Europe. The Scopus database contains articles from 2011 to 2020. Of all articles, the authors have selected only those published in peer-reviewed journals, while have omitted publications in books and conference proceedings. The review of the articles was limited to those written in English. The search result within Scopus yielded a selection of 314 articles published in peer-reviewed journals. After a thorough review of the abstracts and full texts, 70 irrelevant articles were excluded, i.e., those that did not consider the research phenomenon's importance. In this way, it was used to analyse 244 articles published in 127 journals. The systematic literature review is prepared according to the Prisma 2009 technique presented in Figure 1 [18]. 


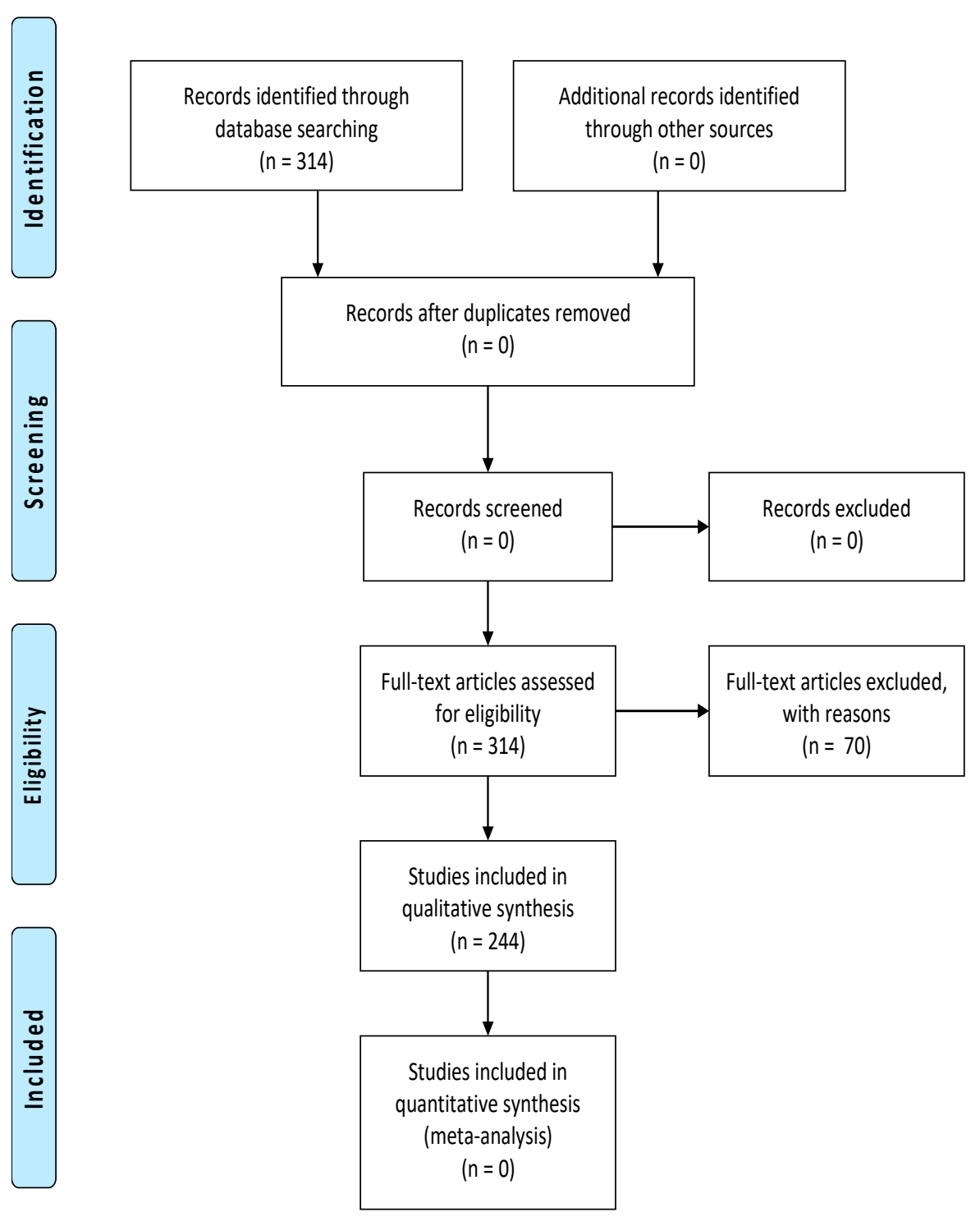

Figure 1. Prisma 2009 flow diagram.

Most of the articles selected for further analysis are from the next scientific journals: Sustainability Switzerland (21), Journal Of Cleaner Production (12), Transportation Research Part A Policy And Practice (10), Transport Policy (8), Transportation Research Part D Transport And Environment (7), International Journal Of Sustainable Transportation (6), Transportation Research Record (6), World Electric Vehicle Journal (6), Applied Energy (5), Research In Transportation Economics (5), Journal Of Advanced Transportation (4), Journal Of Transport Geography (4), Sustainable Cities And Society (4), Technological Forecasting And Social Change (4), Transportation Science (4), European Journal of Operational Research (3), International Journal of Automotive Technology and Management (3), Research in Transportation Business and Management (3), Scientific Reports (3), Transport Reviews (3), Transportation Research Part B Methodological (3), Travel Behaviour and Society (3).

\subsection{Method}

The ACA method is a method for the qualitative and quantitative synthesis of the literature. It is a text-mining tool that uses text parsing and machine learning and focuses on pattern recognition and prediction from data. ACA uses a set of statistical algorithms that can detect concepts in a text [19]. The concepts discovered by the ACA are defined as groups of words that are strongly related in the literature and, therefore, represent a common theme [20]. Leximancer performs content analysis after three stages of the ACA 
process. In the first step, Leximancer identifies concepts using concept seeds extracted from the literature by uncontrolled seeding or provided by the researcher with controlled seeding. In the second step, the ACA Leximancer defines each concept. In the last step, the ACA ranks the concepts according to the weights [21].

\section{Results}

Leximancer created 35 concepts and seven themes from 244 articles published in 127 journals. The authors set the slider Visible Concepts to $100 \%$ and rotated the model for 76 degrees. The theme size was moved from 33\% (automatic) to $47 \%$. A theme is defined as a group or composite of concepts that share common features or connections, as indicated by their spatial proximity in the concept map. The names of themes present the most prominent concepts in related concepts [17]. Table 1 shows themes, hits and related concepts.

Table 1. Themes and concepts.

\begin{tabular}{ccc}
\hline Theme & Hits & Concept \\
\hline sharing & 1097 & sharing, car, transport, mobility, cities, services, urban, sustainable, environmental, development \\
systems & 968 & systems, use, vehicle, public, potential, users, service, private, energy \\
economy & 389 & economy, social, benefits, innovation, countries \\
model & 367 & model, factors, information, market, proposed, power \\
policy & 360 & policy, provide, network, impact, quality, management, tube \\
travel & 267 & travel, cars, modes, people \\
electric car sharing & 247 & electric car sharing, cost, time, work \\
\hline
\end{tabular}

Figure 2 shows the related concepts that are connected to the themes, which are presented in circles. Themes on a Leximancer concept map are heat mapped, and this means that hot colours (red, orange) denote the most important themes, while cool colours (blue, green) denote those less critical [22]. The themes are "sharing «, «systems", »economy«, »model «, "policy«, » travel « and »electrical car sharing «.

Figure 2 shows that the circles of specific themes overlap with the circles of other themes, forming cross-sections that contain individual concepts, which fall into both overlapping themes. For example, the theme »sharing « overlaps with the themes »economy», travel«, »policy« and »systems«. The theme »travel« overlaps with the themes »systems« and "policy«. The theme »systems « overlaps with the themes »sharing «, "policy«, »travel«, »model« and »electric car sharing». The theme »electric car sharing « overlaps with the themes »systems « The theme »model« overlaps with the themes »systems « and »policy«. The theme »economy« overlaps with the themes »sharing « and »policy«.

The concept »car« lies between the intersection of the themes »sharing « and »travel«. The concept »modes « lies between the intersection of the themes »sharing «, »travel « and "systems«. The concept "people« lies between the intersection of the theme's» travel « and »systems«. The concepts »public«, »private« and »services « lie between the intersection of the themes »sharing " and »systems«. The concept »environmental « lies between the intersection of the themes "policy « and "sharing «. The concepts "potential « and »service« lie between the intersection of the themes »systems « and »policy«. The concepts »work «, »time« and »energy « lie between the themes »systems « and »electrical car sharing «. The concepts »market«, »factor « and »information« lie between the themes »model « and »policy«. Finally, the concepts »countries«, »social« and »benefits« lie between the themes »policy« and »economy«. 


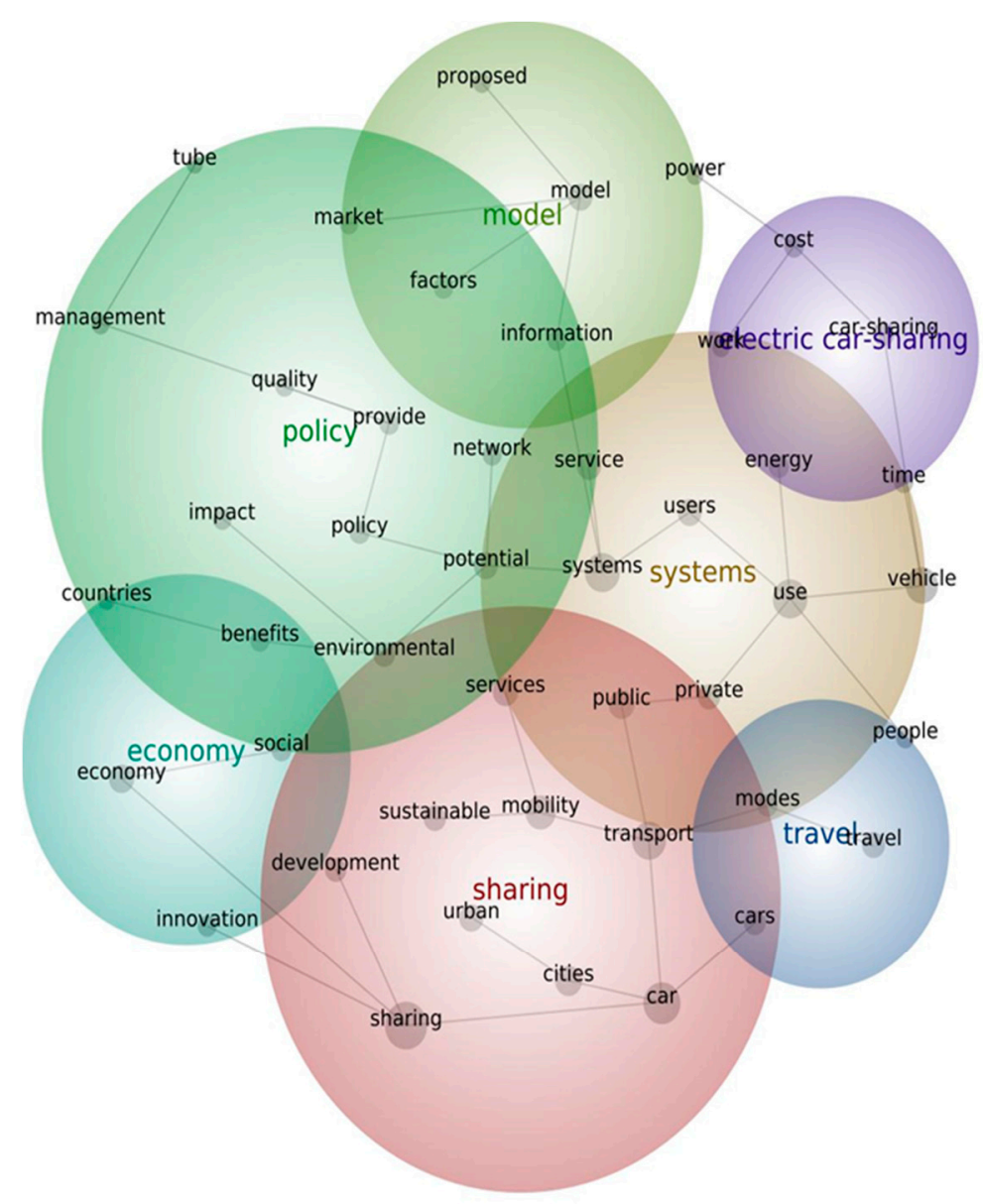

Figure 2. Concept map for selected articles.

\section{Discussion}

With Leximancer 5.0 for ACA, seven themes were identified explaining the car sharing situation in Europe. The seven themes (see Figure 2) regarding the car sharing situation in Europe are Sharing, Economy, Model, Systems, Electrical car sharing, Policy and Travel.

\subsection{Fundamentals of Car Sharing}

\subsubsection{The Review of Car Sharing Development}

The emergence of online internet or digital platforms (thematic: sharing) has had a major impact on the introduction and further development and growth of sharing goods and services in society [23]. The concept of sharing goods and services has been around before the launching of the internet. In the UK, so-called small car sharing was known in the 1970s [24].

In the pre-internet era, the costs associated with finding partners for sharing and creating contracts were paramount. However, the risks associated with sharing before the internet were mainly related to the limited and more difficult to access information about the offer itself, the provider's reliability, and the validity of the contracts [25]. The introduction of the internet has significantly impacted reducing transaction costs between unknown participants in the sharing process. From an economic point of view, transaction costs present all the costs and difficulties (risks) associated with carrying out an economic transaction [26]. In the pre-internet era, the costs associated with finding partners (in newspapers or from mouth to mouth) in the process of sharing and creating contracts were of utmost importance. In Figure 3 are exposed to the main characteristics of the sharing model development. 


\section{Emergence of sharing model}

\begin{tabular}{|c|c|c|}
\hline $\begin{array}{l}\text { Viral customer search } \\
\text { (mouth to mouth) }\end{array}$ & $\begin{array}{l}\text { Newspapers, } \\
\text { magazines, radio and } \\
\text { TV advertising }\end{array}$ & $\begin{array}{c}\text { Digital (internet) } \\
\text { platforms - sharing } \\
\text { economy }\end{array}$ \\
\hline \multirow{5}{*}{$\begin{array}{l}\text { High transactional costs } \\
\text { Limited range } \\
\text { Payment and legal risks }\end{array}$} & High transactional costs & Lower transactional \\
\hline & Higher range but stil & costs \\
\hline & & Unlimited local and \\
\hline & Pavment and legal risks & essibility \\
\hline & & $\begin{array}{l}\text { Online payment system } \\
\text { prepared electronic } \\
\text { contracts reduce } \\
\text { economic and legal risks }\end{array}$ \\
\hline
\end{tabular}

Figure 3. Characteristics of sharing model development.

The sharing economy's fundamental concept is based on the emphasis on the ability, the possibility, and the personal preference of individuals to borrow goods or services instead of buying and owning them. The sharing economy thus enables individuals to monetise underutilised resources. Underutilised resources range from real estate to cars to products such as tools, toys, and clothing. Sharing can be free of charge, or the user pays the sharing costs [2].

The European Economic and Social Committee has defined the sharing economy (theme policy) as a system in which property and services are shared between private individuals, and sharing can be free or for a fee, usually taking place online. The European Commission states that the economics of cooperation refers to business models. Certain economic activities are facilitated by cooperation platforms that create an open market for the temporary use of goods or services that private individuals often provide. In this case, the sharing economy is not limited to activities in which the ownership of a good change, but in most cases implies activities aimed at creating and gaining profit, but it can also refer to voluntary activities (theme economy) [27].

The digitalisation enables the next step in the development of sharing economy. It enables a peer-to-peer (P2P) economic model whose activities are related to the acquiring, providing or sharing access to goods and services between individuals or between businesses and individuals (B2C) and business to business (B2B) [1]. The digital platforms allow faster search sharing providers of goods services and do their transactions through standard contracts that are already met in sharing through online platforms, the process itself is completed through payment services over the internet. The development of digital services has enabled a reduction in transaction costs and greater legal certainty for the tenant, especially with the emergence of blockchain as a disruptive technology that enables smart contracts [28]. In recent years, blockchain technology has spread. It is widely known through the cryptocurrency Bitcoin [29], which, together with credit cards and other digital payment solutions (e.g., mobile applications), forms a digital payment system that is also becoming one of the advantages of digital sharing platform services [30,31]. In practice, digital platforms allow providers to share goods or services, reduce transaction costs and mitigate business risks, but platforms must collect and share information about individual users' past behaviour and reliability. The consumer's role in the sharing economy 
has evolved in two directions, with consumers acting as both acquirers and providers of resources. Digital platforms also allow consumers to approve resource providers [32].

Two groups of business models of car sharing have emerged [33,34]:

- Private organisations (operators) that own a car fleet and enable users that they have access to the cars from the fleet;

- $\quad \mathrm{P} 2 \mathrm{P}$ car sharing is going for organisations that offer to customers, both the owner and the car user. The digital platform enables customers to search, reserving, signing the contract and an insurance and paying.

The P2P car sharing also include a sub-form. It is going for the non-profit type of sharing economy, where goods and services are provided for free (or sometimes for a modest subscription) between the closed group. The juristic characteristic of this type is that the user is signing the contract with the car owner only once, while by commercial type of car sharing, where a business provides a service to customers the contract has to be signed every time before the beginning of the car sharing service [28,29]. In Figure 4, characteristics of both types are shown.

The fundamental dividing line between the definition of car sharing and car rental itself is that car sharing is about the ability to share a car on demand. The demarcation coincides with the idea of providing a public car that can be used as easily as a private car. The concept itself has gained momentum in the last decade by introducing internet technologies and smart devices [24,35]. Collaborative car sharing has taken on a new organisational form centred around digital platforms and smart applications to deliver car sharing services [36-38]. For example, the process of renting a car and the fact that access to the car is not autonomous is more reminiscent of traditional car rental in providers such as Avant2go and Giro car share in Slovenia. However, peer-to-peer providers have also started to experiment with other procedural plans, such as introducing advanced technology to open up private cars, which will enable a new type of car sharing in the future. With peerto-peer technology development, it will probably be possible to distinguish between a private and a public car (thematic systems) [39].

\subsubsection{Car Sharing Types of Services}

In the last ten years, two types of car sharing services in Europe (and the world) were developed. As shown in Figure 5, the transportation model is subdivided into socalled transportation by ride-hailing services, as is the case with Europe Uber and the US-based Lyft. Here, an object is rented together with labor, i.e., human capital, and implies, for example, the rental of a car or other vehicle with the person driving it [40]. In Europe, there is an outcry among taxi drivers because, in their opinion, Uber provides taxi services without a license [41].

According to car sharing in Europe research [32] it can be concluded as it is shown in Figure 6 that operational characteristic of the European car sharing providers with an own fleet based on:

1. Roundtrip station-based or "back to base": a shared car has to be picked up and returned to the same (dedicated) parking spot.

2. Roundtrip home zone-based: a shared car has to be picked up and returned to the same area/(home)zone of the city. (No dedicated parking spots are in play).

3. Free-floating with operational area: a shared car can be picked up and returned in a large operational area. In most cases it is a whole city or even a different city. (No dedicated parking spots are in play).

4. Free-floating with pool-stations: a shared car can be pick up and returned in a large operational area but always in dedicated pool stations. In most cases it is a whole city or even a different city. This kind of service is also known in the literature as one-way station-based car sharing. 
In theory, some concerns can be identified that ride-hailing can be a part of the sharing economy. There is evidence in various research papers that this form should be classified as an on-demand or gig economy [42-44].
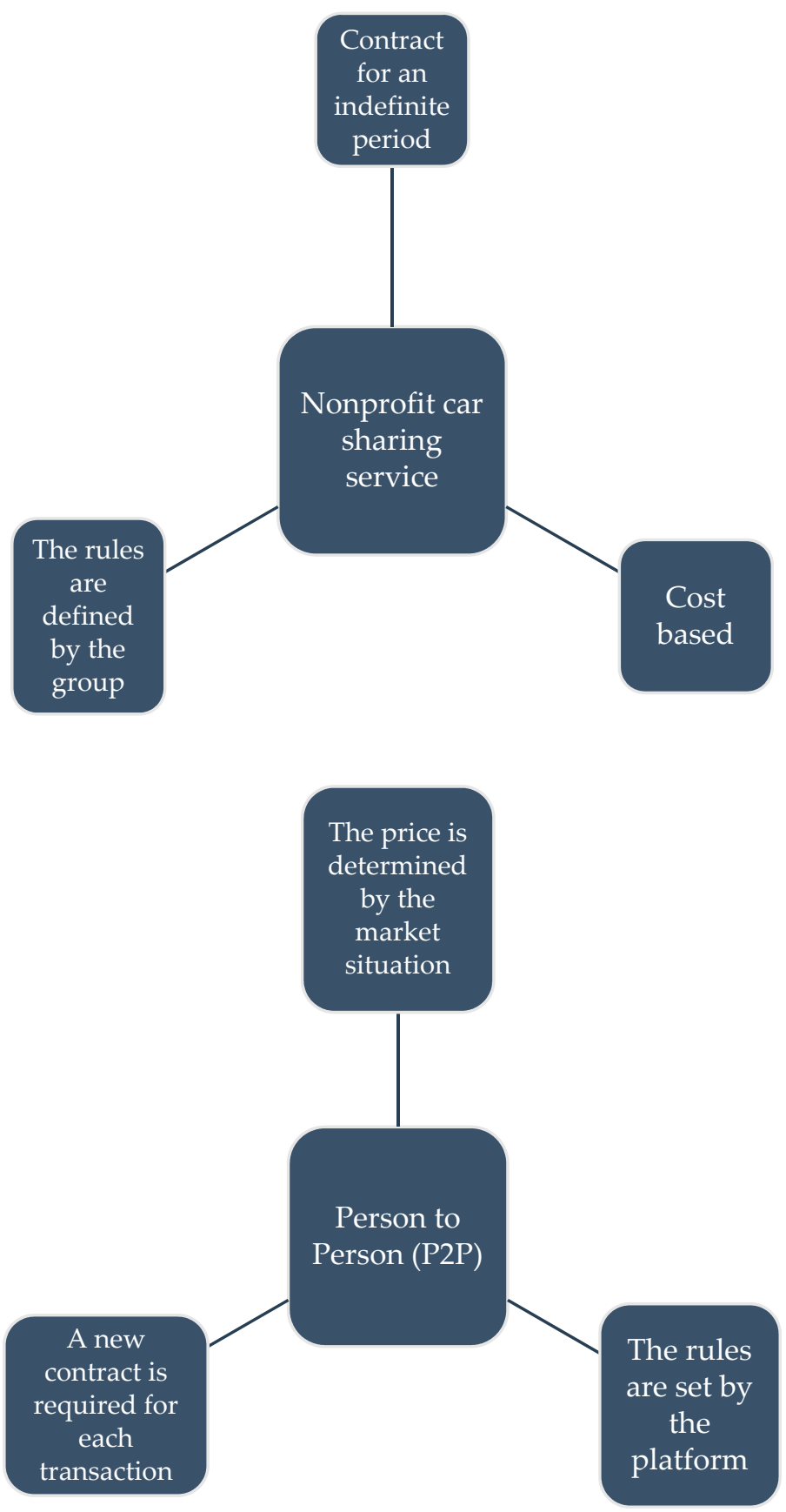

Figure 4. Two ways of sharing owned cars in Europe. The figure is prepared according to the Car Scheme 33. 


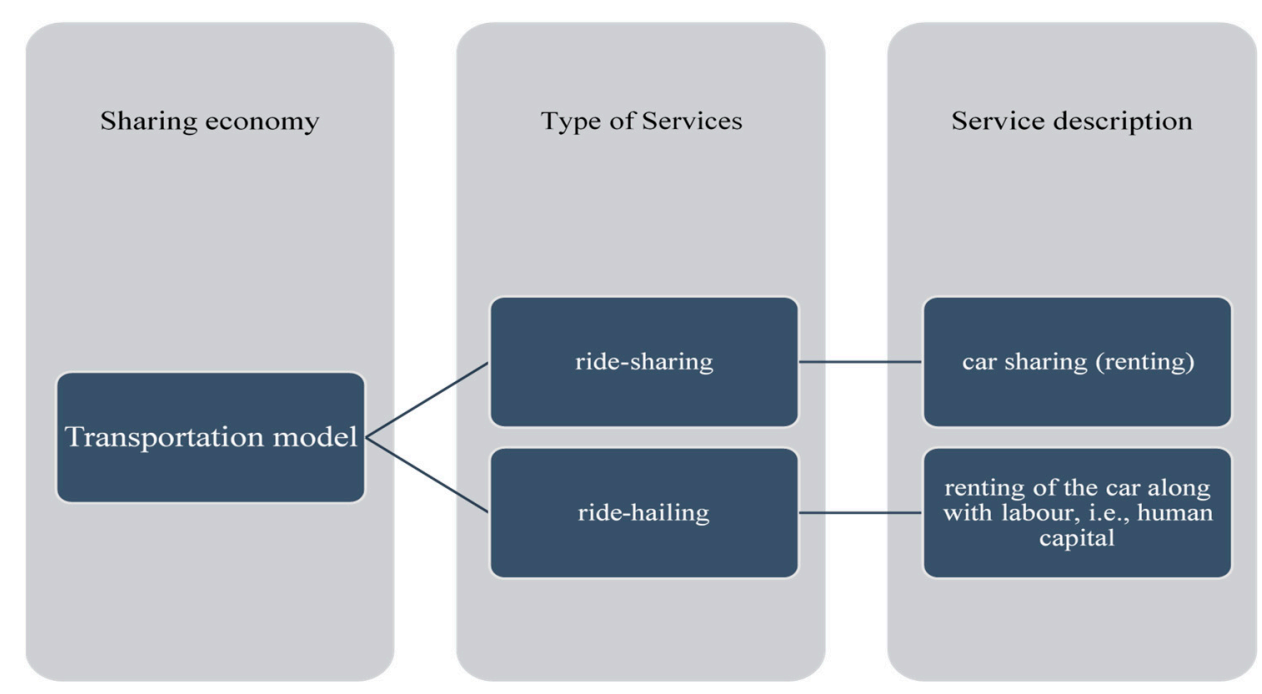

Figure 5. Sharing economy and transportation models.

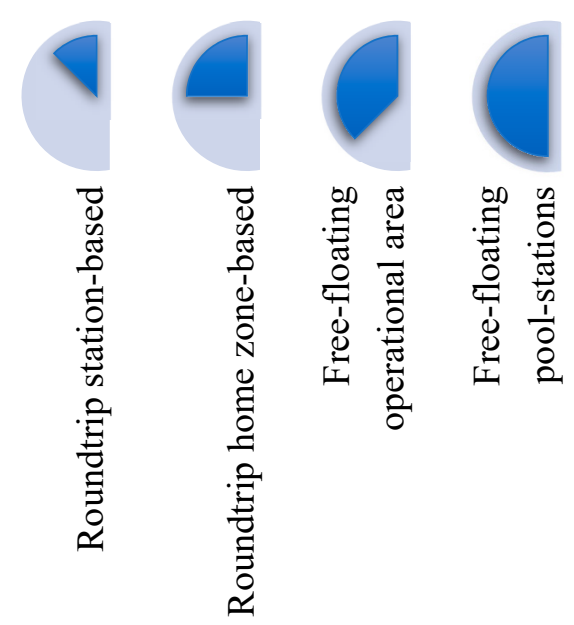

Figure 6. Operational characteristic of the European car sharing providers with an own fleet based.

The second type of service is based on sharing (or renting) the property itself, such as renting a car, bike, or another form of transportation. The second type of collaborative transportation service is based on sharing (or renting) the property itself, such as renting a car, bike, or another form of transportation. It is going for a car sharing platform between individuals, such as GetAround, and corporate car sharing platforms such as, e.g., Enjoy or ZipCar or Car2Go. The Uber allows individuals, drivers to provide transportation, taxi services using their private cars. The Zipcar platform allows individuals to rent a car for shorter distances, such as a short trip or a grocery store trip [30]. Some of the companies in this segment of the sharing economy are ZipCar in the United Kingdom [41], Car2Go in Austria, Denmark, France, Germany, Hungary, Italy, the Netherlands, Spain [45] and Autolib in Austria, Belgium, Czech Republic, Austria, Denmark, Finland, France, Germany, Greece, Hungary, Ireland, Italy, Luxembourg, Netherlands, Norway, Poland, Portugal, Romania, Russia, Spain, Sweden, Switzerland, Turkey and the United Kingdom [46]. Bikes can be rented through the Spinlister [47].

According to the theory, the car sharing model represents an example of a sharing economy, where lending rather than owning an asset is the access to a service that allows better use of the shared asset, making it much cheaper and more accessible to a wider range of people $[31,32,48]$. The research findings also emphasise the role of car sharing in urban environments, as it is a sustainable environmental solution in the context of the electrification of cars (the topic of electric cars). Thus, such a model ensures that no 
harmful emissions are produced, and the sustainable aspect of this car sharing model is further emphasised by the use of electricity from renewable sources [49-52]. The increasing popularity of the car sharing model in recent times is based on electric vehicle fleets' design. Electric vehicles are more suitable than a car with an internal combustion engine. Electric vehicles are characterised by lower operating costs so that the additional price of an electric vehicle pays for itself more quickly in shared fleets than if one person only uses it [53-55].

Policymakers in European countries are increasingly supporting electric car sharing schemes to reduce congestion-related pollution and reduce the need for additional road infrastructure. The provision of shared electric vehicles thus multiplies the effect of positive environmental impacts. It is also important to note that automobile producers themselves have launched their electric car sharing offerings, and they have done so largely to find new ways to regulate congestion and change consumer attitudes [56].

The European car sharing sector hosts a mix of both local players and global OEMs. Our analysis shows that overall, about 45 percent of car sharing providers in Europe already operate a $100 \%$ electric fleet and that this trend is increasing. Experts argue that sharing electric vehicles paves the way for private adoption of electric vehicles, an argument that makes OEMs a better fit. Other concerns revolve around enforcement of laws, such as low-emission zones in cities, while smaller players often cite faith. Take, for example, Aimo (Stockholm), InnogyGo! (Warsaw) Alternatively, ELoop (Vienna) has started building electric-only fleets in their home cities. OEM-funded services for most cities, i.e., fully electric in several cities, will increase electric vehicles' overall share in the total fleet. Simultaneously, about $35 \%$ of vehicle owners still do not have zero-emission cars, while $20 \%$ of providers manage a mixed EV fleet in ICE [57].

The most known OEM's or independent organisations EV in Europe are [57,58]:

- Autolib is a program of City of Paris together with 63 surrounding municipalities. It has over 4300 charging stations and 850 rental kiosks.

- Share Now was created years ago through the merger of BMW DriveNow and Daimler's car2go. The program offers the BMW i3 model and other fuel-powered variants like the 1 Series and Mini. With 3030 e-cars in 15 markets (excluding London, where the service is being discontinued), DriveNow has the largest e-fleet in Europe to date. Four of those markets can boast an all-electric ShareNow fleet, namely Stuttgart, Paris Amsterdam and Madrid. The remaining cities in the mix are Milan, Vienna, Berlin, Hamburg, Munich, Copenhagen, Rhineland, Helsinki, Budapest and Lisbon, with these cities having varying E percentages, ranging from $2 \%$ (Milan) to $45 \%$ (Copenhagen). Overall, share Now is on track to increase the number to at least 4000 electric vehicles.

- The car sharing provider WeShare from Volkswagen and Skoda currently operates the biggest fleet of EVs in one market. WeShare deployed 1500 e-Golfs in Berlin and has plans for ramping up the service to eight cities in 2020, including Paris and Madrid and Budapest, Munich or Milan. The fleet would then amount to around 8400 electric vehicles in total.

EV sharing providers are also proactively addressing increasingly stringent emissions regulations as they seek to secure long-term access to city centers. Madrid has banned the passage of ICEs within the urban area and is now only accessible to electric cars and hybrids with an electric range of more than $40 \mathrm{~km}$. It is going for one reason why the city has become a hotspot for electric vehicle replacement. Among the first to respond were Wible, Kia and energy company Repsol, which operates a fleet of 500 plug-in hybrids in the Spanish capital. Zitty, Emov and Share Now also offer electric vehicles [57].

Opening up new fields has its problems. Charging large EV fleets is one of the challenges platform operators face. Here, providers rely on two to three different pillars. In cities like Berlin or Paris, public charging infrastructure is an integral part of charging vehicles in the business area.

A second pillar is partnering with other private companies to install and operate charging infrastructure. For example, WeShare has announced a strategic alliance with 
Schwarz Group, including retail chains such as Lidl and Kaufland. Both chains roll out charging stations in their parking lots that customers can use during business hours-while the e-car sharing provider uses the charging stations at night [57].

Renault's Moov'in in Paris took a similar approach by partnering with ADA to operate and charge. The vehicles are charged either at public charging points or the charging infrastructure set up on the cooperation's premises. ADA is a leading car rental provider in France with several hubs and branches in and around Paris [57].

While the trend towards electric vehicles increases, cars are, of course, not the only electric vehicles that make good sharing vehicles. While the bigger players like Share Now and WeShare focus on providing cars per minute, smaller, local companies like Poppy in Belgium or Aimo in Sweden show a more innovative approach by adding electric twowheelers to their fleets. Poppy deployed a fleet of electric mopeds and kick-scooters in Antwerp and Brussels that users book through the same app as the car sharing service. Recently, Denmark's all-electric car sharing provider GreenMobility also announced plans to launch 400 electric vehicles in Vienna. GreenMobility has signed a letter of intent with the Austrian Automobile, Motorcycle and Touring Club to merge with the latter's e-scooter sharing service in the Austrian capital [57].

The first data collected shows that a multimodal fleet has synergies on user growth and user activity. Friedel's report [57] shows that users' activity increased by up to 30\% for providers like Aimo or Poppy. In general, users play a significant role on the road to larger EV fleets. It includes increasing environmental awareness and electric cars' positive reception when used for marketing approach in car sharing fleet electrification [59].

For understanding the social relations and economic processes of the car sharing economy, which influenced the socioeconomic development of urban places and launching urban sustainability, it is necessary to understand the historical events.

\subsection{Urban Sustainability and Car Sharing}

\subsubsection{Car Sharing in Europe and Sustainability}

In Europe, car sharing first appeared between 1987 and 1988 and was introduced in 1989 in Germany and Switzerland, where people almost simultaneously came up with the idea of replacing a private car with a shared car. Later, car sharing was introduced in Austria and Denmark in 1997. In Belgium, it has appeared since 2002, in France since 1999. In the UK, the so-called new car sharing was introduced in 1999. In Italy, the concept has been in use since 2009 [37]. In the 1980s, all European cities had centres open to automobile traffic. The negative impact of traffic on the environment in the centres themselves was already becoming apparent, and social groups began to draw attention to it and demand action from the authorities. For example, car sharing advocates suggested that a sharing model should be developed to reduce most households' reliance on cars and introduce more sustainable transport modes (thematic travel). It would take into account that people would not be denied access to cars [60].

The time of car share launching in Germany and Switzerland coincides with the emergence of the idea of sustainability. Thus, citizens' initiatives emerged in cities, calling for a change in urban development policy in line with the then-emerging concept of sustainability, aiming at social well-being and natural harmony [61].

\subsubsection{Emergence of the Urban Sustainability}

Awareness of the importance of sustainable development in the urban environment led, in 1991, to the European Union making urban sustainability one of its main objectives. Research in the 6th and 7th Framework Programs has developed urban sustainability indicators, which are considered the most effective method for assessing urban sustainability and serve as a tool for setting several sustainability targets. However, in 2020, we do not yet have a set of urban planning indicators or assessment, and the topic is not included in EU policy [62]. The importance of sustainable urban indicators and urban planning indicators can be recognised in the definition of urban sustainability of the authors Verma 
and Raghubanshi [63], who pointed out that urban sustainability includes different topics such as biodiversity, energy, material balance, air pollution, heat island, noise pollution and others. The indicators importance is that they show the condition of environmental quality and, on the other, provide the framework for the development of a sustainable urban policy, within which it is necessary to take into account, in our opinion and accordance with the fundamental concept of sustainable development, all three cores of sustainable development, environmental sustainability, economic sustainability and social sustainability.

Why urban planning policies are important in line with sustainable policies and the role of transport in this is shown by the estimate that over $50 \%$ of the world's population now live in urban areas and this is expected to rise to $70 \%$ by 2050 [64]. There is a huge change coming, which will affect both the millions of people moving and the cities to which they are moving. Nevertheless, cities also offer opportunities; humans are social creatures. We thrive in urban spaces that foster social connections. Such urbanisation change presents a challenge to planners and developers, who see rural suburbs as an opportunity to look at them as urban sprawl indicators [65]. Despite what some people think, urban systems can be more environmentally sustainable than rural or suburban living, where people may be further from each other, from essential services and the workplace. With people and resources located so close to one another, it is possible to save energy and resources by effectively planning services such as food transportation and mass transit systems. Cities also benefit the economy by bringing people together in one relatively small area where ideas can easily be generated and developed. Some experts think that cities will be the future growth drivers, stimulating both supply and demand in the economy. Cities need lots of things, but they can provide lots of things and employment opportunities and economic success. However, things can go wrong in cities. If their systems are not well organised or maintained they can have a large negative impact on the environment; they may use large amounts of energy generated in unsustainable ways, they may scar and poison the land and pollute the atmosphere. Technology-based on the Internet of Things and the Internet of Everything, big data, smart mobile apps, etc., has an important role in enabling positive outcomes for cities [66,67]. Today's solutions will be critical in ensuring that tomorrow's cities represent a positive social environment based on sustainability.

In practice and the literature, various experts try to find parallels between the sustainable cities and smart cities [68-70]. By our opinion, a smart city comprises four key urban aspects that are essential for achieving its sustainability (sustainable urban growth and urban economy): (i) density (building density), (ii) mobility and connections (intelligent urban mobility), (iii) mixing of purpose and function (condensation of functions and programs) and (iii) public space and participatory urbanism (involvement of the profession and the public-involvement of all actors in establishing a smart city). These aspects have to be considered and presented if the city wants to realise the urban sustainability goals.

Density is the most critical factor of a sustainable city [71]. The density factor enables us to control the amount of development and manage the number of actors in a given space. The building density process allows for better land use, thus preserving undeveloped land destined for the natural environment or agriculture. The density factor within a smart city can also be used concerning the physical location of the traffic and public transport [72].

Due to the passenger car's affordability and the economy's dependence on constant economic growth, cities are developing large suburban areas, typically characterised by low building density and/or the absence of the intertwining of various functions. Suburbs are attractive for investment because of less complicated ownership situations (usually vast land with few owners) and easier access to the construction process. The result is large suburbia areas, which today are increasingly turning into post-suburbia-a mixture of decentralisation and suburbia urbanisation [73]. The process of post-suburbanisation and the development of smart cities (smart suburbs) could make a significant contribution to sustainable urban planning in the future. The suburbia phenomenon is primarily focused on car use and makes public transport uneconomical, thus removing an essential 
aspect of sustainable cities. Sustainable mobility (transport theme) today means the use of public transport, walking and cycling (bicycle network in the city) and is seen as one of the fundamental approaches to transform cities into sustainable cities, as in the case of Berlin, Helsinki, Copenhagen, Vienna, etc. [74,75]. The importance of sustainable cities also become smart is shown by the role of implementing smart technologies, enabling the development of concepts and models such as car sharing, automated driving, on-demand public transport, and co-travel via mobile applications, etc. [76]. Stakeholders are expected to reach most of their daily needs and services via a smart network or on foot. Mixing goods and services allows for another process in cities to be regulated-gentrification. Policies on balancing interests between different stakeholders prove essential in managing sustainable urban development [77]. Smart city systems, with their data capture and interpretation of data (big data), better define and understand interests. A study carried out in Rome by Mugion et. al. [78] shows that citizens consider it important that the city has a well-developed public transport infrastructure. Thus, quality directly impacts using public transport, which has a positive effect on citizens to use cars less and to use more sustainable modes of transport, which includes the concept of car sharing.

Nevertheless, information and communication technology has reduced the time required for individual transactions, and people can rent cars for an hour as technological changes have drastically simplified the process [79]. Car sharing providers in Europe also face local legislation problems, different consumers' behaviour and competition in local transport. In Germany, for example, a court in Frankfurt banned Uber from operating as a ride-hailing service in 2019 [80]. The court made this decision because, according to the court, the mobility app Uber does not have the proper license to operate in Germany. A case from Paris where was in 2018 came to the collapse of the French car sharing system Autolib, which was operated on a non-profit basis. The collapse was due to increased competition in the alternative transport sector, including hailing apps such as Uber, and poor fleet maintenance [81].

The Deloitte research [82] about car sharing in Europe shows that it is successful in Germany, UK, France, Switzerland, Austria, Netherlands, Sweden, Spain, Belgium, Norway and Denmark. The use of car sharing varies in Europe, depending on the level of car ownership and European countries' geographical characteristics. It is important to note that residents across Europe have begun to adopt car sharing as an alternative form of mobility, as it allows them to retain the features of a private car, but without the cost of ownership [82]. EU rules and air quality standards (theme policy) significantly impact the introduction of alternative public transport and vehicles powered by alternative fuels such as gas and electricity [83]. The use of car sharing can be considered as an alternative sustainable mobility solution because it reduces people's decision to drive, reduces the number of private cars and because car sharing fleet owners increasingly choose to buy electric cars. All these solutions have a positive effect on reduced pollution and greenhouse gas emissions $[84,85]$.

\subsubsection{COVID-19 Impact on Car Sharing}

The COVID-19 pandemic also contributed to understanding smart cities' concept as a sustainable city model in 2020, which led to a change in urban mobility. Cities started to accelerate the construction of pedestrians and cyclists' construction and prepare, together with private partners, a new car or bike-sharing concepts in cities [86]. The outbreak of COVID -19 in 2020 led to the closure of car sharing providers. For example, in Italy, where car sharing is very popular, 60 to $70 \%$ of services are no longer used, while elsewhere, e.g., in Berlin, bike-sharing has increased. It is predicted that the upswing in car sharing will continue after the pandemic. For example, as the pandemic's consequences are expected to cause job losses and revenue losses in this sector, companies focus on new mobile solutions that offer users more cost-flexible approaches (system such as the introduction of "pay-asyou-go") and increase payment via apps. A pandemic's consequences are also likely to be seen in the emergence of innovations based on micro-mobility solutions (sharing scooters, 
bicycles and scooters). It is predicted that the pandemic could promote sustainable mobility in many polluted urban areas [87].

\subsection{Ride-Hailing Practices and Changes in Urban Sustainability}

The best-known provider of the ride-hailing concept in Europe is Uber. With Uber's relatively rapid penetration of the European market, the question arises as to why certain cities in Europe such as London, Frankfurt, Paris, Amsterdam, Rome, Madrid and Zagreb support a model like Uber's. The answer can be found between city governments' goals to enable low-income residents and marginalised groups to access new forms of public transportation by enabling ride-hailing practices. Ride-hailing practices enabling is also beneficial to individuals and families who do not live near traditional public transportation or cannot afford to live in a denser area with well-developed transit access [88-90].

However, city governments need to be aware that affordable ride-hailing services (ondemand transportation) can significantly impact the course of urban planning, economic development, and transportation policies of the city itself. Thus, ride-hailing services can impact on [91,92]:

- Inhibiting transit development: the service could increase migration from densely populated urban areas to suburbia. This situation is coming because Uber picks up users wherever they are, and on the other hand, city subsidies make it cheaper than other modes of transportation. Thus, Uber can also significantly impact reducing the number of private cars and the use of public transport, which can also lead to a change in urban planning (e.g., fewer car parks and roads, increased cycle paths and pedestrian zones) [90,93].

- There is a declining interest in public transportation: Soon, it can be expected the emergence of autonomous vehicles and their integration into ride-hailing services. Such a scenario will allow self-driving vehicles to pick up and drop off people anywhere. The consequences will be a sharp decline in public transportation and the discontinuation of mass transit expansion projects [94].

- Increasing vehicle traffic: a long-term increase in the number of vehicles in the fleets of ride-hailing providers may translate into increased traffic in the future. Investors in companies that provide ride-hailing services anticipate that, in the future, people will choose to own a vehicle less and less, and therefore opt for the ease and technological advancements of ride-hailing services that allow them to reach their desired destination. In the short term, there is a possibility that cities will face increased urban traffic and congestion due to the increased interest in ride-hailing services.

Cities need to address these development concepts and pursue developing a multimodal environment where ride-hailing services are only one of the other forms of development.

After considering the positive changes that ride-hailing services can cope with, it is necessary to analyse this service's negative consequences in European cities.

\subsection{Criticism of the Sharing Economy and Ride-Hailing Practices}

By sharing economy as an economic system (theme economy), it should not be ignored that venture capital plays an important role in developing sharing business models. It is the owners of venture capital who have become the biggest players in the sharing economy and have gained considerable power in the global economy with the help of their rise. The actors have gained such power in the global economy by influencing information asymmetry and the lack of control between the platform and the participants and promoting growing inequality concerns [95]. All of this has led researchers such as Slee [96] and Scholz [97] to argue that the sharing economy has nothing to do with sharing itself. Calo and Rosenblat [98] even point out that it is a business model that takes away its customers. In effect, its owners gain more value from participants while presenting themselves to the outside world as a socially oriented business. Based on these views, Srnicek [99] writes that this new phenomenon of the sharing economy and its business models are better described as 
"a form of platform capitalism" representing the phenomenon of Uber's so-called social costs. Uber practices from different countries, and for which it is even banned in many, are mainly [100]:

- violation of labour legislation (mainly because it does not recognise the status of employees as drivers, regardless of the amount of work they perform);

- violation of legislation setting traffic/workplace safety standards;

- the vulnerability of Uber drivers and customer databases.

The Uber practices include also avoiding paying a fair share of taxes whenever possible. Furthermore, above all, they avoid any responsibility to drivers by not admitting that he is acting as an employer. It must be pointed out that the state should pay attention to citizens' concerns, as Uber is one of those companies that profit from lowering labour standards and precarious work practices [101]. All of this represents a step away from sustainable thinking and represents a gradual disintegration of welfare state systems. Of course, Uber is not the only example of such changes in the labour market; it is neither the first nor the last, as the flexibility of the workforce has become part of everyday life. Therefore, it is essential to open a wider debate- which should also include the general public —on the direction in which things are evolving in work and where we as a society want them to go [102].

There is no problem in application development. However, all that Uber presents as a platform for exploiting workers by denying its role as an employer is not good. The purpose of technology and advancement is to improve people's lives without making them worse.

\section{Conclusions}

The sharing economy is a quite young economic system. In this system, property and services are shared between individuals. Companies operating in the sharing economy have enabled and provided people with a new way of buying and using everyday products and services. Today, the term sharing economy is used to describe an online marketplace that allows users to offer and buy any goods or services. Therefore, in the global market, a new form of competition has emerged for traditional companies. These are the online start-ups of the sharing economy. These web platforms connect people who own a new property with people who want to rent that property for a short period. The type of property these start-ups work with is very different, and it is free time for everyday tasks (example: TaskRabbit, Fiverr), free time and cars for driving people (example: Uber, Lyft). It is important to keep in mind that the sharing economy has boomed incredibly as part of the fourth industrial revolution (after 2011). Therefore, it is no longer a discussion of a monolithic phenomenon, but rather a series of different digital and cyber-physical platforms, business models and transactions [103]. Based on the research carried out, we can assess the gaps in knowledge regarding the procedures of article selection, analysis feature and the purpose of the analysed results.

Author Contributions: The authors V.R., I.P. and M.M. contributed equally. All authors have read and agreed to the published version of the manuscript.

Funding: This research received no external funding.

Institutional Review Board Statement: Not applicable.

Informed Consent Statement: Not applicable.

Data Availability Statement: Not applicable.

Conflicts of Interest: The authors declare no conflict of interest. 


\section{References}

1. Kauffman, R.J.; Naldi, M. Research directions for sharing economy issues. Electron. Commer. Res. Appl. $2020,43,100973$. [CrossRef] [PubMed]

2. Clewlow, R.R. Carsharing and sustainable travel behavior: Results from the San Francisco Bay Area. Trans. Policy 2016, 51, 158-164. [CrossRef]

3. Prieto, M.; Baltas, G.; Stan, V. Car sharing adoption intention in urban areas: What are the key socio-demographic drivers. Trans. Res. Part A Policy Pract. 2017, 101, 218-227. [CrossRef]

4. Ferrero, F.; Perboli, G.; Rosano, M.; Vesco, A. Car sharing services: An annotated review. Sustain. Cities Soc. 2018, 37, 501-518. [CrossRef]

5. Yun, J.J.; Zhao, X.; Wu, J.; Yi, J.C.; Park, K.; Jung, W. Business Model, Open Innovation, and Sustainability in Car Sharing Industry-Comparing Three Economies. Sustainability 2020, 12, 1883. [CrossRef]

6. Joo, J.H. Motives for participating in sharing economy: Intentions to use car sharing services. J. Distrib. Sci. 2017, 15, 21-26.

7. Rogers, B. The social costs of Uber. University of Chicago Law Review. Dialogue 2015, 82, 85.

8. Thelen, K. Regulating Uber: The politics of the platform economy in Europe and the United States. Perspect. Politics 2018, 16, 938-953. [CrossRef]

9. Čičin-Šain, N. Taxing Uber. In Uber-Brave New Service or Unfair Competition. Ius Gentium: Comparative Perspectives on Law and Justice; Marin, J., Petrović, S., Mudrić, M., Lisičar, H., Eds.; Springer: Cham, Switzerland, 2020; Volume 76, pp. 181-198.

10. Hossain, M. The effect of the Covid-19 on sharing economy activities. J. Clean. Prod. 2021, 280, 124782. [CrossRef]

11. Moslem, S.; Campisi, T.; Szmelter-Jarosz, A.; Duleba, S.; Nahiduzzaman, K.M.; Tesoriere, G. Best-worst method for modelling mobility choice after COVID-19: Evidence from Italy. Sustainability 2020, 12, 6824. [CrossRef]

12. Statista. Car Sharing in Germany. Available online: https://www.statista.com/statistics/415310/carsharing-services-number-ofvehicles-germany/ (accessed on 26 December 2020).

13. Kearney. The Demystification of Car Sharing. Available online: https://www.kearney.com/automotive/article?/a/thedemystification-of-carsharing (accessed on 26 December 2020).

14. McGaughey, E. Uber, the Taylor review, mutuality and the duty not to misrepresent employment status. Indiana Law J. 2019, 48, 180-198. [CrossRef]

15. Cherry, C.E.; Pidgeon, N.F. Is sharing the solution? Exploring public acceptability of the sharing economy. J. Clean. Prod. 2018, 195, 939-948. [CrossRef]

16. Ganapati, S.; Reddick, C.G. Prospects and challenges of sharing economy for the public sector. Gov. Inf. Q. 2018, 35, 77-87. [CrossRef]

17. Nunez-Mir, G.C.; Iannone, B.V., III; Pijanowski, B.C.; Kong, N.; Fei, S. Automated content analysis: Addressing the big literature challenge in ecology and evolution. Methods Ecol. Evol. 2016, 7, 1262-1272. [CrossRef]

18. Moher, D.; Liberati, A.; Tetzlaff, J.; Altman, D.G. Preferred reporting items for systematic reviews and meta-analyses: The PRISMA statement. PLoS Med. 2009, 6, e1000097. [CrossRef]

19. Blei, D. Probabilistic topic models. Commun. ACM 2012, 55, 77-84. [CrossRef]

20. Krippendorff, K. Content Analysis: An Introduction to Its Methodology, 3rd ed.; SAGE Publications: Thousand Oaks, CA, USA, 2013.

21. Pucihar, A. The digital transformation journey: Content analysis of Electronic Markets articles and Bled eConference proceedings from 2012 to 2019. Electron. Mark. 2020, 30, 29-37. [CrossRef]

22. Leximancer. Leximancer User Guide. 2020. Available online: https:/ /info.leximancer.com/ (accessed on 5 January 2021).

23. Rohan, P.J.; Furlong, D.A. The No-Buy Pledge: A Potential Tool for Tenants in a Condominium Conversion. William Mitchell Law Rev. 1984, 10, 49.

24. The State of European Car Sharing Final Report D 2.4 Work Package 2. Available online: https://www.eltis.org/sites/default/ files/trainingmaterials/the_state_of_carsharing_europe.pdf (accessed on 26 December 2020).

25. Benkler, Y. Sharing nicely: On shareable goods and the emergence of sharing as a modality of economic production. Yale Law J. 2004, 114, 273-358. [CrossRef]

26. Williamson, O.E. The economics of organisation: The transaction cost approach. Am. J. Soc. 1981, 87, 548-577. [CrossRef]

27. European Commission. Office Journal of the EU2018/C 081/09; p. 66. Available online: https://eur-lex.europa.eu/legal-content/ EN/TXT/PDF/?uri=OJ:C:2018:081:FULL\&from=ES (accessed on 17 January 2021).

28. Nam, K.; Dutt, C.S.; Chathoth, P.; Khan, M.S. Blockchain technology for smart city and smart tourism: Latest trends and challenges. Asia Pac. J. Tour. Res. 2019. [CrossRef]

29. Nelms, T.C.; Maurer, B.; Swartz, L.; Mainwaring, S. Social payments: Innovation, trust, Bitcoin, and the sharing economy. Theory Cult. Soc. 2018, 35, 13-33.

30. Lee, J.Y. A decentralised token economy: How blockchain and cryptocurrency can revolutionise business. Bus. Horiz. 2019, 62, 773-784. [CrossRef]

31. Yli-Huumo, J.; Ko, D.; Choi, S.; Park, S.; Smolander, K. Where is current research on blockchain technology-A systematic review. PLOS ONE 2016, 11, e0163477. [CrossRef] [PubMed]

32. Matzler, K.; Veider, V.; Kathan, W. Adapting to the sharing economy. MIT Sloan Manag. Rev. 2015, 56, 71.

33. Car Sharing in Europe: A Multidimensional Classification and Inventory. Available online: http://stars-h2020.eu/wp-content/ uploads/2019/06/STARS-D2.1.pdf (accessed on 29 December 2020). 
34. Cepolina, E.M.; Farina, A. A new shared vehicle system for urban areas. Transp. Res. Part C Emerg. Technol. 2012, $21,230-243$. [CrossRef]

35. Bardhi, F.; Eckhardt, G.M. Access-based consumption: The case of car sharing. J. Consum. Res. 2012, 39, 881-898. [CrossRef]

36. Standing, C.; Standing, S.; Biermann, S. The implications of the sharing economy for transport. Trans. Rev. 2019, 39, 226-242. [CrossRef]

37. Sutherland, W.; Jarrahi, M.H. The sharing economy and digital platforms: A review and research agenda. Int. J. Inf. Manag. 2018, 43, 328-341. [CrossRef]

38. Uteng, T.P.; Julsrud, T.E.; George, C. The role of life events and context in type of car share uptake: Comparing users of peer-to-peer and cooperative programs in Oslo, Norway. Transp. Res. Part D Transp. Environ. 2019, 71, 186-206. [CrossRef]

39. Grieger, M.; Ludwig, A. On the move towards customer-centric business models in the automotive industry-a conceptual reference framework of shared automotive service systems. Electron. Mark. 2019, 29, 473-500. [CrossRef]

40. Berger, T.; Frey, C.B.; Levin, G.; Danda, S.R. Uber happy? Work and well-being in the 'gig economy'. Econ. Policy 2019, 34, 429-477. [CrossRef]

41. Pakusch, C.; Meurer, J.; Tolmie, P.; Stevens, G. Traditional taxis vs automated taxis-Does the driver matter for Millennials? Travel Behav. Soc. 2020, 21, 214-225. [CrossRef]

42. Sanders, D.E.; Pattison, P. Worker characterisation in a gig economy viewed through an Uber centric lens. South. Law J. 2016, 26, 297.

43. Malos, S.; Lester, G.V.; Virick, M. Uber drivers and employment status in the gig economy: Should corporate social responsibility tip the scales? Empl. Responsib. Rights J. 2018, 30, 239-251. [CrossRef]

44. Zipcar. Available online: https:/ / www.zipcar.com (accessed on 23 December 2020).

45. Car2go. Available online: https://www.fleeteurope.com/en/tags/car2go (accessed on 23 December 2020).

46. Autolib. Available online: https://www.fleeteurope.com/en/tags/autolib (accessed on 23 December 2020).

47. Splinster. Available online: https:/ / www.spinlister.com (accessed on 23 December 2020).

48. Frenken, K.; Schor, J. Putting the sharing economy into perspective. Environ. Innov. Soc. Trans. 2017, 23, 3-10. [CrossRef]

49. Novikova, O. The sharing economy and the future of personal mobility: New models based on car sharing. Technol. Innov. Manag. Rev. 2017, 7, 27-31. [CrossRef]

50. Cruz, I.S.; Katz-Gerro, T. Urban public transport companies and strategies to promote sustainable consumption practices. J. Clean. Prod. 2016, 123, 28-33. [CrossRef]

51. Dlugosch, O.; Brandt, T.; Neumann, D. Combining analytics and simulation methods to assess the impact of shared, autonomous electric vehicles on sustainable urban mobility. Inf. Manag. 2020, 103285, in press.

52. Julsrud, T.E.; Farstad, E. Car sharing and transformations in households travel patterns: Insights from emerging proto-practices in Norway. Energy Res. Soc. Sci. 2020, 66, 101497. [CrossRef]

53. Illgen, S.; Höck, M. Electric vehicles in car sharing networks-Challenges and simulation model analysis. Transp. Res. Part D Transp. Environ. 2018, 63, 377-387. [CrossRef]

54. Folkestad, C.A.; Hansen, N.; Fagerholt, K.; Andersson, H.; Pantuso, G. Optimal charging and repositioning of electric vehicles in a free-floating carsharing system. Comput. Oper. Res. 2020, 113, 104771. [CrossRef]

55. Müller, J.M. Comparing Technology Acceptance for Autonomous Vehicles, Battery Electric Vehicles, and Car Sharing-A Study across Europe, China, and North America. Sustainability 2019, 11, 4333. [CrossRef]

56. Rode, P.; Floater, G.; Thomopoulos, N.; Docherty, J.; Schwinger, P.; Mahendra, A.; Fang, W. Accessibility in cities: Transport and urban form. In Disrupting Mobility; Meyer, G., Shaheen, S., Eds.; Springer: Cham, Switzerland, 2017; pp. $239-273$.

57. Friedl, A. Current Development and Future Trends: Free Floating Car Sharing Report 2020. Available online: https://www. dropbox.com/s/keaudxjq9aje2on/2020\%20Free\%20Floating\%20Car\%20Sharing\%20Report.pdf (accessed on 29 December 2020).

58. Statista. In Depth e-Mobility 2020. Available online: https://www.statista.com/study/49240/emobility/ (accessed on 29 December 2020).

59. Lemme, R.F.; Arruda, E.F.; Bahiense, L. Optimization model to assess electric vehicles as an alternative for fleet composition in station-based car sharing systems. Transp. Res. Part D Transp. Environ. 2019, 67, 173-196. [CrossRef]

60. Hansen Henten, A.; Windekilde, I.M. Transaction costs and the sharing economy. Info 2016, 18, 1-15. [CrossRef]

61. Gardner, J.; Roseland, M. Thinking Globally and Acting Locally Part II: Acting Locally: Community Strategies for Equitable Sustainable Development. Perspect. Soc. Technol. Environ. 1989, 16, 36-48.

62. Corredor-Ochoa, Á.; Antuña-Rozado, C.; Fariña-Tojo, J.; Rajaniemi, J. Challenges in assessing urban sustainability. In Urban Ecology; Verma, P., Singh, P., Singh, R., Raghubanshi, A.S., Eds.; Elsevier: Amsterdam, The Netherlands, 2020 ; pp. 355-374.

63. Verma, P.; Raghubanshi, A.S. Urban sustainability indicators: Challenges and opportunities. Ecol. Ind. 2018, 93, $282-291$. [CrossRef]

64. Angel, S.; Parent, J.; Civco, D.L.; Blei, A.; Potere, D. The dimensions of global urban expansion: Estimates and projections for all countries, 2000-2050. Prog. Plan. 2011, 75, 53-107. [CrossRef]

65. Epstein, J.; Payne, K.; Kramer, E. Techniques for mapping suburban sprawl. Photogr. Eng. Remote Sens. 2002, 68 , 913-918.

66. Sánchez-Corcuera, R.; Nuñez-Marcos, A.; Sesma-Solance, J.; Bilbao-Jayo, A.; Mulero, R.; Zulaika, U.; Azkune, G.; Almeida, A. Smart cities survey: Technologies, application domains and challenges for the cities of the future. Int. J. Distrib. Sens. Netw. 2019, 15. [CrossRef] 
67. Sokolov, A.; Veselitskaya, N.; Carabias, V.; Yildirim, O. Scenario-based identification of key factors for smart cities development policies. Technol. Forecast. Soc. Chang. 2019, 148, 119729. [CrossRef]

68. Yigitcanlar, T.; Kamruzzaman, M.; Buys, L.; Ioppolo, G.; Sabatini-Marques, J.; da Costa, E.M.; Yun, J.J. Understanding' smart cities': Intertwining development drivers with desired outcomes in a multidimensional framework. Cities 2018, 81, 145-160. [CrossRef]

69. Ahvenniemi, H.; Huovila, A.; Pinto-Seppä, I.; Airaksinen, M. What are the differences between sustainable and smart cities? Cities 2017, 60, 234-245. [CrossRef]

70. Brorström, S.; Argento, D.; Grossi, G.; Thomasson, A.; Almqvist, R. Translating sustainable and smart city strategies into performance measurement systems. Public Money Manag. 2018, 38, 193-202. [CrossRef]

71. La Greca, P.; Barbarossa, L.; Ignaccolo, M.; Inturri, G.; Martinico, F. The density dilemma. A proposal for introducing smart growth principles in a sprawling settlement within Catania Metropolitan Area. Cities 2011, 28, 527-535. [CrossRef]

72. Salomons, E.M.; Pont, M.B. Urban traffic noise and the relation to urban density, form, and traffic elasticity. Landsc. Urban Plan. 2012, 108, 2-16. [CrossRef]

73. Moroke, T.; Schoeman, C.; Schoeman, I. Developing a neighbourhood sustainability assessment model: An approach to sustainable urban development. Sustain. Cities Soc. 2019, 48, 101433. [CrossRef]

74. Bottero, M.; Caprioli, C.; Cotella, G.; Santangelo, M. Sustainable cities: A reflection on potentialities and limits based on existing eco-districts in Europe. Sustainability 2019, 11, 5794. [CrossRef]

75. Evans, J.; Karvonen, A.; Luque-Ayala, A.; Martin, C.; McCormick, K.; Raven, R.; Palgan, Y.V. Smart and sustainable cities? Loc 2019, 24, 557-564.

76. Bibri, S.E.; Krogstie, J. On the social shaping dimensions of smart sustainable cities: A study in science, technology, and society. Sustain. Cities Soc. 2017, 29, 219-246. [CrossRef]

77. McBride, M.F.; Lambert, K.F.; Huff, E.S.; Theoharides, K.A.; Field, P.; Thompson, J.R. Increasing the effectiveness of participatory scenario development through codesign. Ecol. Soc. 2017, 22, 16. [CrossRef]

78. Mugion, R.G.; Toni, M.; Raharjo, H.; Di Pietro, L.; Sebathu, S.P. Does the service quality of urban public transport enhance sustainable mobility? J. Clean. Prod. 2018, 174, 1566-1587. [CrossRef]

79. Basili, M.; Rossi, M.A. Platform-mediated reputation systems in the sharing economy and incentives to provide service quality: The case of ridesharing services. Electron. Commer. Res. Appl. 2020, 39, 100835. [CrossRef]

80. Politico. Available online: https:/ / www.politico.eu/article/uber-germany-court-ruling/ (accessed on 27 December 2020).

81. France 24. Available online: https://www.france24.com/en/20180621-france-paris-end-road-carsharing-system-autolib (accessed on 27 December 2020).

82. Deloitte. From Now on. Available online: https://www2.deloitte.com/content/dam/Deloitte/it/Documents/strategy/Deloitte_ Future_of_mobility_COVID19_ENG.pdf (accessed on 27 December 2020).

83. Ramos, É.M.S.; Bergstad, C.J.; Chicco, A.; Diana, M. Mobility styles and car sharing use in Europe: Attitudes, behaviours, motives and sustainability. Eur. Transp. Res. Rev. 2020, 12, 13. [CrossRef]

84. Mounce, R.; Nelson, J.D. On the potential for one-way electric vehicle car sharing in future mobility systems. Transp. Res. Part A Policy Pract. 2019, 120, 17-30. [CrossRef]

85. Liao, F.; Molin, E.; Timmermans, H.; van Wee, B. Carsharing: The impact of system characteristics on its potential to replace private car trips and reduce car ownership. Transportation 2020, 47, 935-970. [CrossRef]

86. Zhou, F.; Zheng, Z.; Whitehead, J.; Perrons, R.K.; Washington, S.; Page, L. Examining the impact of car sharing on private vehicle ownership. Transp. Res. Part A Policy Pract. 2020, 138, 322-341. [CrossRef]

87. Roblek, V.; Thorpe, O.; Bach, M.P.; Jerman, A.; Meško, M. The Fourth Industrial Revolution and the Sustainability Practices: A Comparative Automated Content Analysis Approach of Theory and Practice. Sustainability 2020, 12, 8497. [CrossRef]

88. De Souza Silva, L.A.; de Andrade, M.O.; Maia, M.L.A. How does the ride-hailing systems demand affect individual transport regulation? Res. Transp. Econ. 2018, 69, 600-606. [CrossRef]

89. Tirachini, A. Ride-hailing, travel behaviour and sustainable mobility: An international review. Transportation 2020, 47, $2011-2047$. [CrossRef]

90. Lavieri, P.S.; Bhat, C.R. Investigating objective and subjective factors influencing the adoption, frequency, and characteristics of ride-hailing trips. Transp. Res. Part C Emerg. Technol. 2019, 105, 100-125. [CrossRef]

91. Gerwe, O.; Silva, R. Clarifying the sharing economy: Conceptualisation, typology, antecedents, and effects. Acad. Manag. Perspect. 2020, 34, 65-96. [CrossRef]

92. Van Dijck, J.; Poell, T.; De Waal, M. The Platform Society: Public Values in a Connective World; Oxford University Press: New York, NY, USA, 2018.

93. Bruns, A.; Matthes, G. Moving into and within cities-Interactions of residential change and the travel behavior and implications for integrated land use and transport planning strategies. Travel Behav. Soc. 2019, 17, 46-61. [CrossRef]

94. Narayanan, S.; Chaniotakis, E.; Antoniou, C. Shared autonomous vehicle services: A comprehensive review. Transp. Res. Part C Emerg. Technol. 2020, 111, 255-293. [CrossRef]

95. Cosenz, F.; Qorbani, D.; Yamaguchi, Y. An exploration of digital ride-hailing multisided platforms' market dynamics: Empirical evidence from the Uber case study. Int. J. Prod. Perform. Manag. 2020, in press. [CrossRef]

96. Slee, T. What's Yours is Mine: Against the Sharing Economy; OR Booksm: New York, NY, USA, 2015. 
97. Scholz, T. Uberworked and Underpaid: How Workers Are Disrupting the Digital Economy; Polity Press: Cambridge, UK, 2017.

98. Calo, R.; Rosenblat, A. The taking economy: Uber, information, and power. Columbia Law Rev. 2017, 117, 1623-1690. [CrossRef]

99. Srnicek, N. The challenges of platform capitalism: Understanding the logic of a new business model. Juncture 2017, 23, 254-257. [CrossRef]

100. Malin, B.J.; Chandler, C. Free to work anxiously: Splintering precarity among drivers for Uber and Lyft. Commun. Cult. Crit. 2017, 10, 382-400. [CrossRef]

101. Vallas, S.P. Platform capitalism: What's at stake for workers? New Labor Forum 2018, 28, 48-59. [CrossRef]

102. Linder, T. Surveillance capitalism and platform policing: The surveillant assemblage-as-a-service. Surveill. Soc. $2019,17,76-82$. [CrossRef]

103. Cheng, M. Sharing economy: A review and agenda for future research. Int. J. Hosp. Manag. 2016, 57, 60-70. [CrossRef] 